\title{
Konsep Keseimbangan dalam Pemberlakuan Penghentian Penuntutan Berdasarkan Keadilan Restoratif
}

\author{
La Ode Awal Sakti ${ }^{\star}$ \\ 1 Universitas Sembilanbelas November Kolaka \\ “Korespondensi: laodeawalsakti@gmail.com
}

\begin{tabular}{c}
\hline Info Artikel \\
\hline Diterima 20 \\
Oktober 2021 \\
Disetujui 27 \\
November 2021 \\
Dipublikasikan 28 \\
November 2021 \\
\hline Keywords: \\
Konsep \\
Keseimbangan, \\
Penghentian \\
Penuntutan, \\
Keadilan Restoratif, \\
Perlindungan \\
Hukum \\
\hline
\end{tabular}

(c) 2021 The Author(s): This is an open-access article distributed under the terms of the Creative

Commons

Attribution ShareAlike (CC BYSA 4.0)

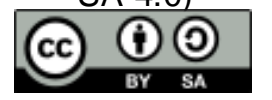

\section{Abstrak}

Pembaharuan dalam sistem hukum pidana terkait penghentian penuntutan berdasarkan keadilan restoratif dianggap perlu untuk dilakukan analisis konsep keseimbangan perlindungan pelaku dan korban tindak pidana. Penelitian ini bertujuan untuk menganalisis dan menjelaskan konsep keseimbangan perlindungan pelaku dan korban tindak pidana dengan adanya penghentian penuntutan berdasarkan keadilan restoratif. Metode penelitian ini adalah normatif, menemukan suatu aturan hukum, prinsipprinsip hukum, maupun doktrin-doktrin hukum guna menjawab isu hukum yang dihadapi. . Hasil penelitian menunjukkan bahwa dengan adanya penghentian penuntutan berdasarkan keadilan restoratif pelaku tindak pidana mendapatkan perlindungan hukum diantaranya perkara diselesaikan di luar proses peradilan, terhindar dari perampasan kemerdekaan dan efek negatif yang ditimbulkan sistem peradilan pidana seperti dehumanisasi (menurunnya nilai kemanusiaan), prisonisasi (pengaruh pembelajaran kejahatan) dan stigmatisasi (cap jahat). Sedangkan perlindungan hukum terhadap korban diwujudkan dengan memulihkan keadaan seperti semula dengan cara mengembalikan barang kepada korban, mengganti kerugian korban dan biaya yang ditimbulkan serta memperbaiki kerusakan akibat tindak pidana yang dilakukan. Pemberlakuan merupakan bentuk penyelesaian yang mampu melahirkan win-win solutions bagi semua pihak.

\section{Abstract}

Reforms in the criminal law system related to the termination of prosecution based on restorative justice are considered necessary to analyze the concept of balancing the protection of perpetrators and victims of criminal acts. This study aims to analyze and explain the concept of balancing the protection of perpetrators and victims of criminal acts with the termination of prosecution based on restorative justice. This research method is normative, for discovering the legal rules, legal principles or legal doctrine to answer the legal issue. The results of the study indicate that with the termination of prosecution based on restorative justice, the perpetrators of criminal acts get legal protection including: cases are resolved outside the judicial process, avoiding deprivation of liberty and the negative effects caused by the criminal justice system such as humanization (decreased human values), prisonization (influence of learning crime) and stigmatization (bad label). Meanwhile, legal protection for victims is realized by restoring the situation to its original state by returning goods to the victim, compensating the victim and the costs incurred and repairing the damage caused by the crime committedt. 
Enforcementis a form of settlement that is able to give win-win solutions for all parties.

\section{Pendahuluan}

Ada berbagai alasan mengapa suatu perkara dapat dihentikan menurut peraturan KUHAP. Untuk memulai, subjek yang ada tidak memiliki cukup bukti. Kedua, bukan pelanggaran atau kejahatan. Ketiga, penarikan penuntutan dengan alasan bahwa subjek telah diadili atau diselesaikan oleh hukum. Suatu perkara dianggap selesai karena alasan hukum apabila tersangka/terdakwa meninggal dunia, nebis in idem, dan telah kadaluwarsa. (Harahap, 2012)

Hapusnya penuntutan pidana secara garis besar dibagi menjadi dua yaitu alasan-alasan penghapus penuntutan yang terdapat didalam KUHP dan alasanalasan penghapus penuntutan pidana yang berada diluar KUHP. Alasan penghapus penuntutan yang terdapat dalam KUHP terdiri dari ne bis in idem, meninggalnya tersangka/terdakwa, daluwarsa dan penyelesaian diluar pengadilan. Sedangkan alasan-alasan penghapus penuntutan pidana diluar KUHP adalah amnesti dan abolisi. (Hiariej, 2014)

Selain beberapa alasan pengentian penuntutan yang diuraikan diatas, dalam pembaharuan hukum pidana terdapat pemberlakuan penghentian penuntutan berdasarkan keadilan restoratif. Hal ini sesuai dengan ketentuan Peraturan Kejaksaan Nomor 15 Tahun 2020 tentang Penghentian Penuntutan Berbasis Keadilan Restoratif. Keadilan restoratif didasarkan pada premis bahwa kejahatan adalah tindakan terhadap orang atau masyarakat dan dikaitkan dengan pelanggaran standar hukum (Marlina, 2012).

Penghentian penuntutan berdasarkan keadilan restoratif merupakan salah satu perbaikan hukum pidana positif di Indonesia. Pada hakekatnya, ketika mengembangkan atau mereformasi hukum pidana, seseorang mengembangkan atau memperbarui pemikiran/konsep/gagasan mendasar, tidak hanya artikulasi literal pasal-pasalnya. Konsep utama yang dieksplorasi dalam reformasi hukum di masa depan adalah apa yang secara kasar dapat disebut sebagai konsep keseimbangan. Salah satu konsep keseimbangan yang dikembangkan adalah keseimbangan antara kepentingan umum/kepentingan masyarakat dan kepentingan pribadi. Sedangkan konsep penyeimbangan kepentingan masyarakat dan individu termasuk konsep penyeimbangan individualisasi pidana dan perlindungan korban (Arief, 2013).

Keseimbangan antara perlindungan korban dan konsep individualisasi pidana dapat dilihat dalam pengaturan pidana dan hukuman. Prosedur pidana dan pemidanaan secara historis mengutamakan kepentingan pelaku tindak pidana, sedangkan sistem peradilan yang tidak sah seringkali mengabaikan rasa keadilan yang dirasakan oleh korban tindak pidana. (Gunarto, 2012)

Ide keseimbangan antara perlindungan kepentingan korban dan individualisasi pidana dimaksudkan agar dalam suatu sistem peradilan pidana kepentingan korban kejahatan (victim of crime) dapat diberikan perlindungan disamping itu juga ada usaha untuk memperlakukan lebih manusiawi pelaku tindak pidana (Muladi, 2008). 
Dengan adanya individualisasi pidana diharapkan pidana yang dijatuhkan dapat mendukung proses pemasyarakatan, serta mencegah stigma terpidana sebagai korban dari sistem peradilan pidana yang tidak adil. (Gunarto, 2012).

Maka dibuatlah pembaruan hukum oleh kejaksaan yang berkaitan dengan keadilan restoratif dalam penghentian penuntutan. Aturan yang dilahirkan menjadi jalan keluar pilihan bagi pelaku tindak pidana dimana menjadi wewenang jaksa. Dimana aturan tersebut harus memperhatikan berbagai kepentingan, yaitu kepentingan negara, kepentingan umum, kepentingan individu, kepentingan pelaku tindak pidana dan kepentingan korban kejahatan. Kemudian, hal yang menjadi perhatian adalah hasil perwujudan dari peraturan perundang-undangan tersebut dalam penyelesaian tindak pidana bagi pelaku, korban dan masyarakat harus dapat memberikan rasa keadilan, kepentingan korban dan pelaku tindak pidana tetap harus mendapatkan perhatian agar kepentingan mereka dapat terlindungi.

Berdasarkan uraian latar belakang sebagaimana yang dikemukakan di atas, maka tujuan dilakukan penelitian ini adalah untuk menjelaskan konsep keseimbangan perlindungan pelaku dan korban tindak pidana dengan adanya penghentian penuntutan berdasarkan keadilan restoratif.

\section{Metode Penelitian}

Metode penelitian yang digunakan dalam penelitian ini adalah normatif. Jen is penelitian hukum normatif yaitu suatu proses untuk menemukan suatu aturan hukum, prinsip-prinsip hukum, maupun doktrin-doktrin hukum guna men jawab isu hukum yang dihadapi (Marzuki, 2010).

Sedangkan sifat penelitian yang digunakan adalah bersifat deskriptif. Penelitian bersifat deskriptif karena semata-mata menggambarkan suatu objek guna menggambil kesimpulan yang berlaku secara umum (Hadi, 2000). Berdasarkan bentuknya termaksud penelitian evaluative alam penelitian hukum. Dikatakan penelitian evaluatif karena penelitian ini dilakukan untuk menilai kon sep keseimbangan perlindungan pelaku dan korban tindak pidana dengan adanya penghentian penuntutan berdasarkan keadilan restoratif.

\section{Hasil Penelitian dan Pembahasan}

Pembaharuan hukum pidana di Indonesia merupakan salah satu usaha untuk mewujudkan tujuan nasional yaitu melindungi segenap bangsa Indonesia dan memajukan kesejahteraan umum. Ada dua maksud dalam tujuan nasional yang terlihat yaitu adanya asas keseimbangan dan pembangunan nasional. Dalam hal ini konsep keseimbangan dalam penghentian penuntutan dan perlindungan terhadap pelaku tindak pidana berdasarkan keadilan restoratif.

\subsection{Konsep Keseimbangan dalam Penghentian Penuntutan Berdasarkan Keadilan Restoratif}

Pengertian keseimbangan didirikan di atas landasan filosofis yang terkandung dalam Pancasila, bukan pada keyakinan in dividualis/liberalis atau kolektivis/sosialis, tetapi pada sifat yang melekat pada kodrat manusia, yaitu monodualisme, yaitu sebagai makhluk individu dan sosial. (Gunarto, 2012)Dalam kerangka evolusi hukum pidana, cita-cita Pancasila menjadi landasan sistem hukum nasional. Pancasila adalah ide/konsep dasar, nilai filosofis yang tercermin dari setiap perintah. "ide keseimbangan". (Maerani, 2015) 
Selain itu falsafah Pancasila yang dikaitkan dengan teori hukum integratif, maka keadilan restoratif memang dibutuhkan dalam hukum pidana Indonesia. Sekalipun bertentangan dengan konsep hukum yang sangat positivis, namun falsafah Pancasila menekankan pada nilai keadilan dan musyawarah dalam penyelesaian masalah hukum. Oleh karena itu, menjadi penting menyusun atu ran keadilan restoratif dalam pembaharuan hukum di Indonesia. (Akbar, 2021)

Penegasan dalam hukum pidana dijelaskan oleh pengertian keseimbangan kepentingan individu dan kepentingan kolektif, itulah yang dimaksud dengan "keseimbangan" dalam masyarakat monodual. (Gunarto, 2012)

Dalam pembaharuan hukum pidana konsep keseimbangan merupakan konsep yang digunakan dalam penyusunan RUU KUHP. Materi konsep KUHP ingin disusun dengan bertolak pada berbagai pokok pemikiran yang secara garis besar dapat disebut "ide keseimbangan". Ide keseimbangan ini, antara lain mencakup (Arief, 2013):

a) Keseimbangan monodualistik antara "kepentingan umum/ masyarakat" dan kepentingan individu/ perorangan". Dalam ide keseimbangan "kepentingan umum/ individu" itu tercakup juga ide keseimbangan perlindungan/ kepentingan korban dan ide individualisasi pidana.

b) Keseimbangan antara unsur/ faktor "obyektif" (perbuatan/ lahiriah) dan "subyektif" (orang/ batiniah/sikap batin).

c) Keseimbangan antara kriteria "formal dan materiel".

d) Keseimbangan antara "kepastian hukum", "kelenturan/ elastisitas/ fleksibilitas", dan "keadilan".

Pergeseran dari retributive justice ke restorative justice merupakan pergeseran konsep keadilan yang melandasi hukum positif sebagai landasan hukum yang nyata dalam ranah hukum pidana dan sistem peradilan pidana.Memulihkan harmoni/keseimbangan itu sendiri tidak cukup; Jadi, pemulihan keseimbangan sebagai sarana untuk mencapai keadilan hanya dapat diterima jika keseimbangan moral yang sudah ada sebelumnya antara pelaku dan korban yang pantas. (Arofa, 2020)

Penuntutan dihentikan karena alasan teknis dan pertimbangan kebijakan. Pemutusan penuntutan karena alasan teknis terjadi apabila penuntut umum memutuskan untuk tidak melakukan penuntutan, sedangkan penghentian penuntutan karena alasan kebijakan terjadi apabila penuntut diizinkan untuk mengesampingkan perkara meskipun ada cukup bukti untuk dilimpahkan ke pengadilan demi kepentingan kepentingan umum atau kepentingan individu.

Menurut syarat-syarat tersebut di atas, suatu perkara dapat dihentikan untuk kepentingan hukum apabila terjadi penyelesaian di luar pengadilan, yaitu apabila denda maksimum untuk suatu tindak pidana tertentu dibayarkan secara sukarela sesuai dengan ketentuan peraturan perundang-undangan. Atau, casing telah dikembalikan ke kondisi aslinya menggunakan konsep keadilan restoratif.

la berpendapat bahwa cita-cita esensial keadilan restoratif berakar pada nilainilai kuno budaya tradisional, seperti konsep keseimbangan, harmoni, dan perdamaian (Amdani, 2016). 
Berdasarkan uraian diatas, dari beberapa konsep keseimbangan yang ada, dalam penelitian ini penulis memfokuskan pada konsep keseimbangan perlindungan pelaku tindak pidana dan perlindungan kepentingan korban. Kon sep keseimbangan perlindungan kepentingan korban dan ide individualisasi pidana pada dasarnya lahir karena bergesernya konsep keadilan itu sendiri.

\subsection{Perlindungan Hukum Pelaku dalam Penghentian Penuntutan Berdasarkan Keadilan Restoratif}

Salah satu alasan untuk menjatuhkan tuntutan adalah untuk mengatasi konflik di luar pengadilan dengan menggunakan prosedur keadilan restoratif. Penuntutan berbasis keadilan restoratif melindungi pelaku kejahatan dengan menangani hal-hal di luar proses pengadilan, mencegah perampasan kebebasan, dan menghindari dampak negatif dari sistem peradilan pidana. Dehumanisasi (nilai kemanusiaan yang lebih rendah), penjara (efek kejahatan pembelajaran), dan stigmatisasi (label negatif) semuanya dapat dicegah.

Persoalan penyelesaian perkara pidana yang hampir selalu berujung pidana penjara akhir-akhir ini diselesaikan melalui kewenangan penuntut umum untuk menghentikan penuntutan berdasarkan konsep keadilan restoratif, khususnya Peraturan Kejaksaan Republik Indonesia Nomor 15 Tahun 2020 tentang Penundaan Penuntutan berdasarkan keadilan restoratif. Ide ini harus dipelajari karena melibatkan penjahat, individu pemenang, dan saksi.

Penuntutan berbasis keadilan restoratif tidak dapat dihentikan dengan segera; melainkan, persyaratan tertentu harus dipenuhi. Kriteria pertama harus diperhatikan ketika penuntutan keadilan restoratif dihentikan, terutama hak-hak korban dan hak-hak hukum yang dilindungi lainnya, penghindaran stigma negatif, pencegahan retribusi, reaksi, dan kerukunan masyarakat; dan kepatutan, kesusilaan, dan ketertiban umum.'

Bentuk perlindungan hukum bagi pelaku tindak pidana dalam rangka penghentian penuntutan berbasis keadilan restoratif, sesuai ketentuan Peraturan Kejaksaan Agung Nomor 15 Tahun 2020 tentang Pemberhentian Penuntutan Jaksa Penuntut Umum mempunyai kewenangan untuk menutup perkara secara hukum. alasan di bawah Keadilan Restoratif. Perkara ditutup demi hukum dengan berbagai cara, antara lain ketika terdakwa meninggal, penuntutan pidana berakh ir, putusan pengadilan yang mempunyai kekuatan hukum tetap terhadap pihak lain dalam perkara yang sama (nebis in idem), aduan pidana adalah ditarik atau ditarik; atau kasus tersebut diselesaikan di luar pengadilan (proses afdoening buiten).

Dalam hal lain, bentuk perlindungan korban, ketika mengembangkan kebijakan penghentian penuntutan berbasis keadilan restoratif, penghentian hanya dapat terjadi dengan persetujuan korban, yang berarti bahwa kepentingan korban tetap dipertimbangkan selama proses musyawarah untuk memberikan perlindungan terbaik bagi korban. kepentingan korban.

Berdasarkan syarat dapat dikatakan bahwa dalam materi muatan Peraturan Kejaksaan Agung Nomor 15 Tahun 2020 tentang Penghentian Penuntutan Berdasarkan Keadilan Restoratif telah mewujudkan konsep keseimbangan perlindungan pelaku tindak pidana dan perlindungan kepentingan korban. Pelindungan pelaku tindak pidana diwujudkan dengan penghindaran stigma negatif dan perhindaran pembalasan sedangkan perlindungan kepentingan korban 
diwujudkan dengan perhatian kepentingan korban dan kepentingan hukum lain yang harus dilindungi. Syarat penghentian penuntutan berdasarkan keadilan restoratif tidak hanya menitikberatkan para perlindungan pelaku dan korban dalam arti sempit tetapi dalam kebijakan formulasi ini juga memberikan perlindungan hukum kepada masyarakat secara umum.

Selain itu, jika persyaratan berikut dipenuhi, tuntutan pidana dapat diakhiri untuk tujuan hukum dan penuntutan berdasarkan keadilan restoratif dapat dihentikan: Untuk memulai, tersangka telah melakukan pelanggaran pertamanya. Kedua, tindak pidana diancam dengan pidana denda atau pidana penjara paling lama lima (lima) tahun. Ketiga, tindak pidana dilakukan dengan nilai barang bukti atau nilai kerugian tidak lebih dari Rp. 2.500.000.00. (dua juta lima ratus ribu rupiah).

Unsur-unsur berikut harus diikuti untuk menghentikan penuntutan berdasarkan keadilan restoratif: tersangka mengembalikan situasi ke keadaan semula; tercapai kesepakatan damai antara korban dan tersangka; dan masyarakat merespon dengan baik. Proses perdamaian bersifat sukarela, deliberatif, dan bebas dari paksaan, intimidasi, atau tekanan. Jaksa Penuntut Umum adalah koordinator inisiatif dalam hal ini.

Penyelesaian perkara pidana yang melibatkan pelaku, korban, masyarakat, dan aparat penegak hukum, khususnya penuntut umum, dilakukan untuk memberikan keadilan sosial bagi semua pihak. Selain itu, kepentingan dan keadilan forum dipertimbangkan dan diupayakan untuk dipenuhi semaksimal mungkin. Tujuan utama keadilan restoratif adalah mengembalikan situasi ke keadaan semula (restutio in integrum). Dengan demikian, pembahasan keadilan restoratif mencontohkan kehadiran Pancasila dalam kehidupan sehari-hari masyarakat Indonesia. Keadilan restoratif menawarkan beberapa manfaat, termasuk meningkatkan partisipasi korban dalam sistem peradilan pidana Indonesia dan memfasilitasi prosedur pengadilan yang jauh lebih efektif dan efisien. Penyelesaian kasus pidana termasuk semua pihak memajukan tujuan keadilan. (Akbar, 2021)

Berdasarkan hal-hal tersebut di atas, diharapkan permasalahan tersebut akan ditangani melalui penggunaan keadilan restoratif untuk memastikan bahwa semua pihak yang merasa dirugikan dibayar dan bahwa korban kejahatan diakui dan dihormati. Penghormatan ditunjukkan kepada korban dengan meminta agar pelaku pulih dari akibat kejahatannya. Bila pengertian ini diterapkan, maka membuka peluang bagi korban (victim-driven) untuk menyampaikan kerugian moneter dan moral yang dideritanya sebagai akibat dari perbuatan jahat pelaku. (Marlina, 2012)

Penyelesaian tindak pidana kejaksaan melalui penggunaan keadilan restoratif yang menekankan pada pemulihan pada keadaan semula serta keseimbangan perlindungan dan kepentingan antara korban dan pelaku tindak pidana nonpembalasan, merupakan tuntutan hukum bagi masyarakat dan merupakan mekanisme yang harus dimasukkan ke dalam penuntutan dan pelaksanaan otoritas reformasi. sistem peradilan. Penuntutan keadilan restoratif ditarik sebagai pilihan terakhir atas dasar keadilan, kepentingan umum, proporsionalitas, dan kejahatan; mereka juga cepat, sederhana, dan ekonomis (Beritno, 2020) 
Kebijakan hukum pidana dalam penanggulangan tindak pidana melalui upaya penyelesaian di luar proses hukum positif saat ini dalam prakteknya ditujukan untuk tercapainya "solusi sama-sama untung" atau "win-win solution", yang dapat menguntungkan kedua pihak (Abildanwa, 2016).

Kebijakan penuntutan individu dengan pendekatan restoratif ditentukan oleh fakta bahwa korban diikutsertakan untuk mencapai tujuan menjatuhkan hukuman dan untuk memastikan hak mereka untuk berpartisipasi aktif dalam proses pengadilan. Tujuan penerapan hukuman adalah untuk menentukan apakah korban telah pulih, kepuasannya, jumlah kompensasi, pengetahuan pelaku tentang tindakannya, jumlah perjanjian perbaikan yang dibuat, kualitas layanan kerja yang diberikan, dan keseluruhan proses (Wahyudi, 2011).

Selanjutnya, dalam politik hukum pidana untuk pembentukan peraturan perundang-undangan pidana perlu memperhatikan aspek social policy yang penyesuaiannya terdiri atas aspek social defence (perlindungan masyarakat) dan social welfare (kesejahteraan masyarakat). Menurut penulis Peraturan Kejaksaan Nomor 15 Tahun 2020 tentang Penghentian Penuntutan berdasarkan keadilan restoratif sendiri dapat dikatakan telah memenuhi aspek-aspek tersebut. Menurut argumen pembelaan sosial, mengakhiri penuntutan berdasarkan keadilan restoratif dapat melindungi pelaku kegiatan kriminal dari konsekuensi hukuman yang berbahaya, serta membantu korban pulih dari keadaan awalnya, dan juga dapat membantu membangun perdamaian. Sedangkan dari perspektif kesejahteraan sosial, jika restorative justice berhasil, pelaku akan dikeluarkan dari proses pemidanaan; dengan mengecualikan pelaku, anggaran negara untuk melahirkan narapidana anak otomatis akan berkurang; dan untuk Lapas akan mencegah terjadinya Over Capacity di Lapas. Hal ini karena keadilan restoratif pada dasarnya didasarkan pada empat konsep (Hasan, 2007).

Pertama, membina kerjasama antara pelaku, korban, dan kelompok masyarakat dalam menangani suatu kejadian atau kejahatan. Kedua, mendesak pelaku kejahatan untuk bertanggung jawab terhadap mereka yang dirugikan oleh peristiwa atau tindakan kriminal. Ketiga, membingkai kejadian atau tindak pidana tidak hanya sebagai pelanggaran hukum, tetapi sebagai pelanggaran yang dilakukan oleh seseorang (atau sekelompok individu) terhadap orang lain (sekelompok orang). Keempat, mendukung resolusi informal dan pribadi atas peristiwa atau tindakan kriminal daripada resolusi resmi (ketat) dan impersonal .

\section{Kesimpulan}

Pemberlakuan penghentian penuntutan yang dilakukan di luar proses peradilan menyesuaikan dengan Peraturan Kejaksaan Nomor 15 Tahun 2020 tentang penghentian penuntutan berdasarkan keadilan restoratif, mewujudkan perlindungan hukum bagi kedua belah pihak serta masyarakat. Terjadinya kon sep keseimbangan melalui adanya perlindungan hukum bagi pelaku tindak pidana, yaitu menghindari perampasan hak. kebebasan, dan menghindari dampak negatif dari sistem peradilan pidana, seperti dehumanisasi (penurunan nilai-nilai kemanusiaan), prisonisasi (pengaruh pembelajaran kejahatan) dan stigmatisasi (cap jahat), serta pemenjaraan (bad label), sedangkan perlindungan hukum bagi korban kejahatan dicapai dengan mengembalikan barang-barang tersangka yang diperoleh selama kejahatan kepada korban, membayar kerugian kepada korban, menutupi pengeluaran yang dikeluarkan, dan/atau memperbaiki kerusakan akibat 
tindak pidana. Pemberlakuan keadilan restoratif dalam penghentian penuntutan merupakan bentuk penyelesaian yang mampu melahirkan win-win solutions bagi semua pihak.

\section{Daftar Pustaka}

Abildanwa, T. (2016). Mediasi Penal Sebagai Upaya Dalam Rangka Pembaharuan Hukum Pidana Di Indonesia Berbasis Nilai-Nilai Keseimbangan. Jurnal Pembaharuan Hukum, 3(1), 138. https://doi.org/10.26532/jph.v3i1.1353

Akbar, M. F. (2021). Keadilan Restoratif dalam Sistem Peradilan Pidana sebagai Perwujudan Nilai-Nilai Pancasila. Justitia Et Pax, 37(1), 85-101.

Amdani, Y. (2016). Konsep Restorative Justice Dalam Sistem. Al-Adalah, XIII(1), 61-76.

Arief, B. N. (2013). Kapita Selekta Hukum Pidana. Bandung: Citra Aditya Bakti.

Arofa, E. (2020). Penghentian Penuntutan Dalam Perkara Pidana Berdasarkan Restorative Justice, 7, 319-338.

Beritno, P. (2020). Penghentian Penuntutan Berdasarkan Peraturan Kejaksaan Republik Indonesia Nomor 15 Tahun 2020 Tentang Penghentian Penuntutan Berdasarkan Keadilan Restoratif, 6(2), 190-206.

Gunarto, M. P. (2012). Asas Keseimbangan Dalam Konsep Rancangan UndangUndang Kitab Undang-Undang Hukum Pidana. Jurnal Mimbar Hukum, 24(1), 83-97. https://doi.org/10.22146/jmh.16143

Hadi, S. (2000). Metodologi Research I. Yogyakarta: Andi Offset.

Harahap, Y. (2012). Pembahasan Permasalahan dan Penerapan KUHAP. Jakarta: Sinar Grafika.

Hasan, A. (2007). Penyelesaian Sengketa Hukum Berdasarkan Adat Badamai Pada Masyarakat Banjar Dalam Kerangka Sistem Hukum Nasiowal. Retrieved from https://dspace.uii.ac.id/handle/123456789/9400

Hiariej, E. O. . (2014). Prinsip-Prinsip Hukum Pidana. Yogyakarta: Cahaya Atma Pustaka.

Maerani, I. A. (2015). Implementasi Ide Keseimbangan Dalam Pembangunan Hukum Pidana Indonesia Berbasis Nilai-Nilai Pancasila. Jurnal Pembaharuan Hukum, 11(2), 329-338. Retrieved from http://jurnal.unissula.ac.id/index.php/PH/article/view/1364

Marlina. (2012). Peradilan Pidana Anak Di Indonesia. Bandung: Refika Aditama.

Marzuki, P. M. (2010). Penelitian Hukum. Jakarta: Kencana.

Muladi. (2008). Pembaharuan Hukum Pidana Materiil Indonesia (Makalah Disamapaikan Pada Seminar dan Kongres ASPEHUPIKI). Bandung.

Wahyudi, S. (2011). Implementasi Ide Diversi Dalam PembaharuanSistem Peradilan Pidana Anak Di Indonesia. Yogyakarta: Genta Publishing. 